
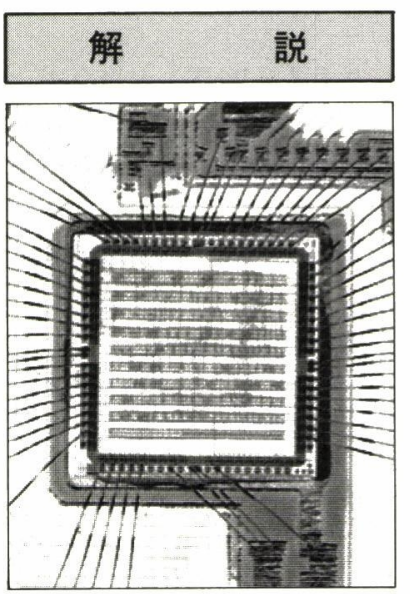

\section{ガスセンサとハイブリッド技術(光の2)}

Technologies of Hybrid and Gas Sensors (II)

\title{
二田 穂積*
}

\section{2 バルク制御形電気低抗式センサ}

この方式は気相ガスとの反応により半導体にバルク組 成 (格子欠陥) が酸化還元に変化し, その結果, 素子の 電気抵抗が変化する原理のものである。組成が変わって も構造が安定であることが必要である。可熱性がス検知 用および燃焼制御用の 2 種類があり, 前者は比較的還元 を受けやすい酸化物で素子を作成して，300〜 $500^{\circ} \mathrm{C}$ の温 度で使用するのに対して, 後者は難還元性の酸化物を用 いて素子を作成し, 比較的高温で動作させることを特徵 とする。

\subsection{1 可燃性ガス検知用センサ}

焼結体素子としては $\gamma$-酸化鉄センサ ${ }^{13)}$ が実用化され ている。LPガスの選択性が高く, 水蒸気やアルコール の影響を受けにくい特徵をもつ。素子低抗值はがス濃度 が増すと低下するが, それと同時に $\mathrm{Fe}^{2+}$ イオン濃度の増 大が見られ $\gamma-\mathrm{Fe}_{2} \mathrm{O}_{3}$ が還元され高導電性の $\mathrm{Fe}_{3} \mathrm{O}_{4}$ に近 づくためと考えられる。厚膜素子としては, $\mathrm{La}_{1-x} \mathrm{Sr}_{x} \mathrm{CoO}_{3}$ で表わされる。ペロブスカイト酸化物 ( $\mathrm{P}$ 型) アルコー ルセンサとして発表されている14)。

\section{2 .2 燃焼制御用センサ}

この形のセンサは，エンジンの空燃比制御を目的に開 発された $\mathrm{TiO}_{2}$ 焼結体素子が実用化されている。この素 子は理論空燃比で電気抵抗が急変するので当量近傍での 制御性は良好である。しかし, 希薄燃焼(リーンバーン) 領域では, $\mathrm{n}$ 型であるため高抵抗となり, 制御性がよく ない。このセンサは素子部に温度補償用の高温型のサー ミスタが取り付けられて使用されている。Fig. 9 に $\mathrm{TiO}_{2}$ 焼結体素子15)の特性を示す。この他，ボイラ等の燃焼監 視用として, $\mathrm{SnO}_{2}$ 系やぺロブスカイト.系のものが発表

${ }^{*}$ Hozumi Futata

矢崎計器 / YAZAK METER CO.,LTD.
されている。この手のセンサでは，ハイブリッド化まで 研究されているセンサはないと考えられる16),17。

\section{3 非電気抵抗式センサ}

電気抵抗以外の物性に着目したセンサとして, FET方 式とダイオード方式がある。電気抵抗式よりも作動温度 が低いという特性を有するが, 対象としうるがスが $\mathrm{H}_{2}$ やCO等の反応性の高いものに現在のところ限られてお ク，大気の活れに弱い等実用面から見た場合まだ問題点 が多い。しかし，この方式のものは発想がュニークで, 超小型化, インテリジェント化が可能であり, 今後の展 開が期待される。

\subsubsection{FET方式}

pdゲートMOSFET (metal-Oxide-semiconductor, field-effect-transistor) センサが約 10 年前Lundströmら

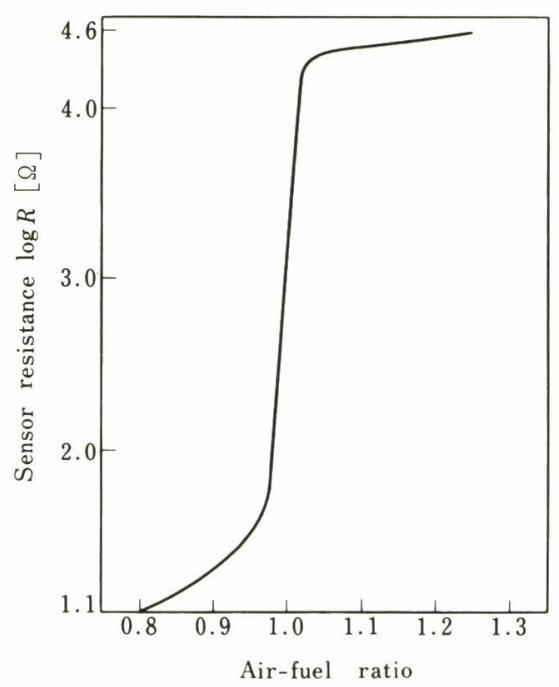

Fig. 9 Characteristics of a typical $\mathrm{TiO}_{2}$ Sensor ${ }^{15}$ (at. $700^{\circ} \mathrm{C}$ ) 


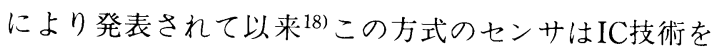
直接用いられるセンサとして注目を集め, 特に外国にお いて活発な研究が行われ，ようやく実用化の段階にさし かかっている。Fig.10にこのセンサの構造を示す。

MOS-FETではゲート電圧によってドレーン電流を制御 するが，そのゲート金属を水素透過性の Pd 膜で置き換 之て, 水素存在下では水素が $\mathrm{Pd}$ 膜を透過して $\mathrm{Pb} / \mathrm{SiO}_{2}$ 界 面で分極し，その分極が実効ゲート電圧を強めるように 作用する。実際には，ドレーン電流がちょうど流れ始め るゲートのしきい值電圧が，水素濃度とともに低下する ことを水素検知に利用している。数ppmの水素を検知で きるほど高感度であるが, 当初のものは安定性に問題が あった。最近, Fig. 10 (b) のように $\mathrm{Pd} / \mathrm{SiO}_{2} / \mathrm{Si}(\mathrm{MOS})$ 構造から $\mathrm{Pd} / \mathrm{Al}_{2} \mathrm{O}_{3} / \mathrm{SiO}_{2} / \mathrm{Si}(\mathrm{MAOS})$ 構造にすること によって, 安定性の向上が図られている。FETセンサ は作動温度が $150^{\circ} \mathrm{C}$ 以下に抑えられるので, 披検がスの 種類が限られ，応答速度もあまり大きくない。しかし， ゲート構造や表面処理によって, $\mathrm{H}_{2}$ 以外にも $\mathrm{NH}_{3} や \mathrm{C}$ Oの測定が試みられている。Fig.11にCOガス用の構 造を示す。このように，本質的に高温に弱い等の弱点の ためガスセンサとしての複合化には至っていないようで あるが, あまり高温動作を要しない湿度，あるいはイオ ン測定等の用途には多機能センサとしての応用が進めら れている21,22)。

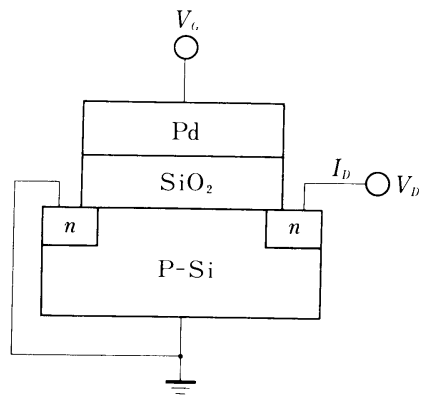

(a ) Pd-MOS

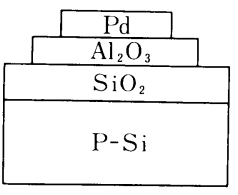

(b) Pd-MAOS
Fig. 10 FET-type sensor 18),19)

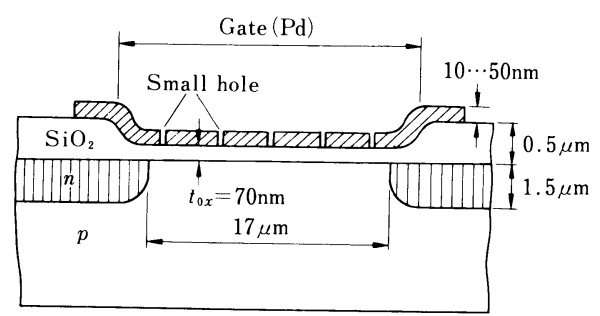

Fig. 11 Cross section of Pd-gate MOSFET element detective $\mathrm{CO}$ gas ${ }^{20}$

\section{3 .2 ダイオード方式}

金属一半導体接合ダイオード素子は金属と半導体を接 合すれば電荷の移動が起って，接合面にショットキー障 壁が生じ整流作用が表われる。この作用ががス吸着によ り変化することをガスセンサに利用する。例えば $\mathrm{Pd}-$ $\mathrm{TiO}_{2}$ 素子では, 電流一電圧曲線は空気中の $\mathrm{H}_{2}$ 濃度によっ てFig. 12のように変化する23)。したがって，一定バイア ス電圧下での電流值，あるいは一定電流を与えるバイア 又電圧値から $\mathrm{H}_{2}$ 濃度を知ることができる。同構造の $\mathrm{Au}^{-}$ $\mathrm{TiO}_{2}$ 素子は常温で $1 \mathrm{ppm}$ 程度のシランガス $\left(\mathrm{SiH}_{4}\right)$ に も応答する ${ }^{24)}$ 。FET万式と同様に安定性の面で, もう一 歩であるが, MOS構造を用いたこの夕イプの素子の研 究等は盛んに行われている。

\subsection{3 ダイオード式の複合化の試みの例}

〔例 1 〕25) ゲート金属による特性を調べるために $1 つ$ のSi基盤上に 6 個のMIS (Metal-Insulator-Semicondu ctor）ガスセンサを組み合わせた例をFig. 13の写真に示

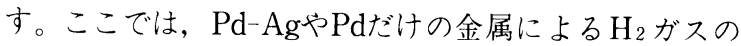
応答速度の違いや, $\mathrm{H}_{2}, \mathrm{O}_{2}, \mathrm{NO}_{2}$ 混合気中の特性を調 べている。

〔例２〕26)この例は，MISガスセンサを実用的に使用 するために，集積化デバイスを作成した例である。Fig. 14 にそのパターン図を示す。これは，pnのSiの上に水素 センサ用のダイオードとトランジスタを載せ，さらにま ったく同じ構造でPd膜だけを外したものを，それぞれ参 照用として配置してある。基盤中央に発熱用卜ランジス

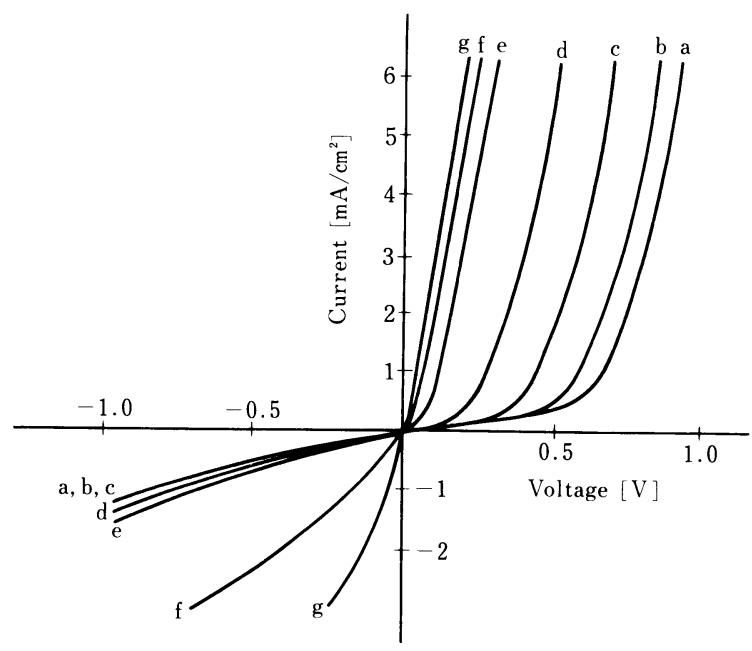

a : in air, b: $14 \mathrm{ppm}, \mathrm{c}: 140 \mathrm{ppm}$, d : 1400ppm, e: $7150 \mathrm{ppm}$, f: $1 \%$, g: $1.5 \%$

(b g : hydrogen concentration in air, at $25^{\circ} \mathrm{C}$ )

Fig. 12 Current-voltage characteristics of $\mathrm{Pd} / \mathrm{TiO}_{2}$ diode element 23) 


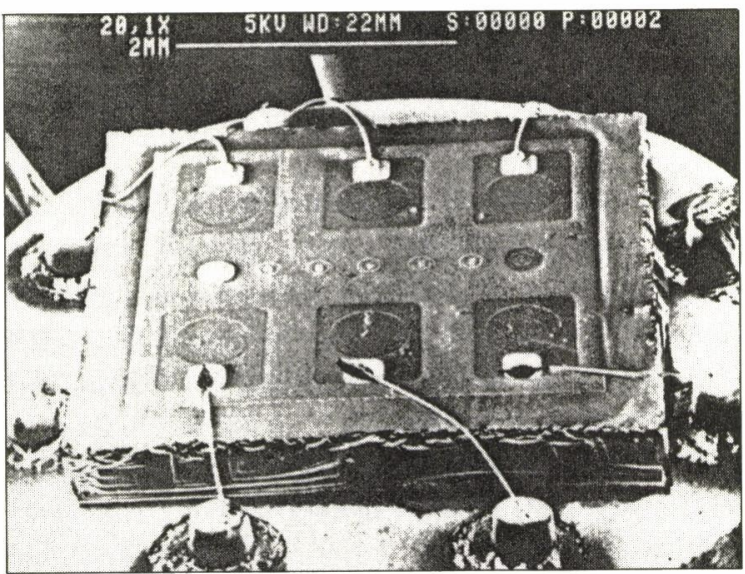

Fig. 13 Scanning Election Micrchcope (SEM) picture of the diode array mounted in a $\mathrm{TO}-5$ header. The $2 \mathrm{~mm}$ dimension marker is at the top. The small circles in the center are alignment marks for the metallization masks ${ }^{25)}$

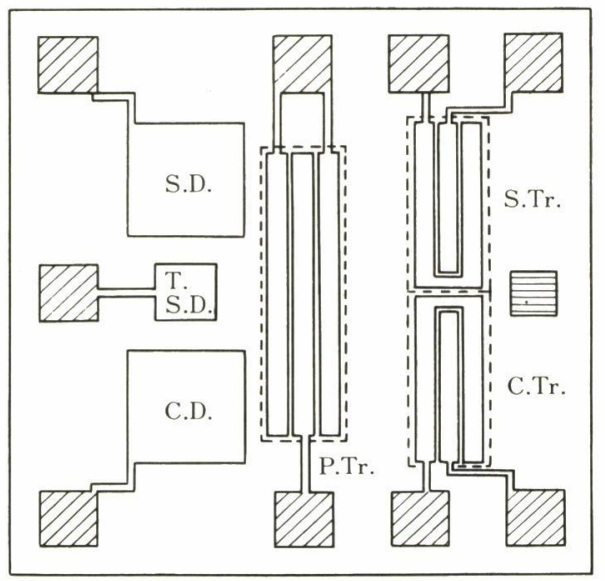

Fig. 14 Pattern of an integrated hydrogen switching sensor fixed with a heater ${ }^{26)}$

夕を置き，TSDは基盤温度測定用のダイオードである。

\section{4. 固体電解質ガスセンサ}

固体電解質は特定のイオンだけを選択的に透過させる 機能をもっている。これを隔膜として用い, 特定のガス を反応物質とする電気化学セルをつくれば, その起電力 あるいは電流值からガスを検知定量することができる。 最もよく用いられる方式は, 固定電解質隔膜の両側のガ 又分圧の違いによる濃淡分極（平衡起電力）を測定する タイプであるが, このような平衡起電力ではなく, 混成 電位を測る方式のセンサも有用である。電流值を出力信

Vol. 5, No. 2

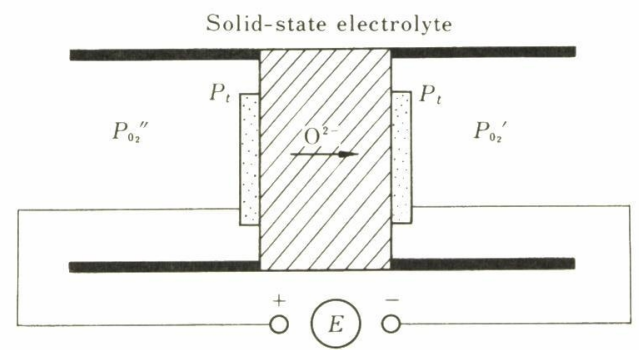

Fig. 15 Schematic structure of the solid-state electrolyte sensor $\left(\mathrm{PO}_{2}^{\prime \prime}>\mathrm{PO}_{2}^{\prime}\right)$

号とするものにも，電解電流および短絡電流を用いる二 つの方式がある。

\section{1 平衡起電力検出方式}

この方式の代表は, 安定化ジルコニア酸素センサであ る。Fig. 15 に示すように $\mathrm{ZrO}_{2}$ に $\mathrm{CaO} \mathrm{Y}_{2} \mathrm{O}_{3}$ 等を約 $10 \%$ モル固溶した安定化ジルコニア（酸素イオン導電体）を 障壁とし，その両側に多孔性白金電極を取り付けて電気 代学セルをつくる。両極のガス雺囲気の酸素分圧を $\mathrm{PO}^{\prime} 2$ および $P_{o 2}{ }^{\prime \prime}$ とすれば, この系は素酸濃淡電地となり, 次 のNernst式に従う起電力を生じる。

$$
E=R T / 4 F \cdot \ln P_{o 2}{ }^{\prime \prime} / P_{o 2}{ }^{\prime}
$$

したがって，一方の極の酸素分圧 $P_{o 2} 2^{\prime}$ が概知（基準） であれば，起電力より他方の極に流す披検ガス中の酸素 分圧 $P_{02} 2^{\prime}$ を知ることができる。一定 $P_{o 2}$ ”を得るには, 標 準ガス（空気など）を流すか金属一酸化物采の平衡酸素 圧を利用する。ところで，センサとして安定な動作を得 るには，少なくても500程度以上の高温にしなければ ならないが, 最近ではより低い温度で安定に使用するた めに, 材料の検討あるいはジルコニア電解質のフッ酸処 理等により, 作動温度が $300^{\circ} \mathrm{C}$ 程度まで下げて使用され ている。このようなセンサは, 現在, ボイラや自動車工 ンジンの空燃比制御, 溶解金属中の酸素活量測定などに 実用化されている27。形状的には，かなり大きい構造を したものが多い。

\section{2 電流検出方式}

安定化ジルコニア (ディスク) の両測に電極をつけ, その一方をシールして小さな孔のキャピラリを介しての み外気に通じるようにする。今，シールした側の電極を 負に，他方の電極を正にする向きの電圧を印加すれば酸 素はシールした側から他方へと吸み出される。印加電圧 を大きくすれば，酸素の吸み出し速度はしだいに大きく なるが、ついにはキャピラリを通しての酸素の拡散が律 速となり飽和する。この時の限界電流は外気の酸素分圧 に比例するので，この值から酸素分圧を知ることができ る。実際には，キャピラリの代わりにスピネル多孔質層 
(約600 $\mu \mathrm{m} ）$ をがスの拡散層とするもが開発されている ${ }^{28)}$ Fig. 16に限界電流の基本特性を示す。この夕イプは, 酸 素濃度依存性がよく, 小型化され, 酸素濃度測定用に実 用化されている29)。最近, 多孔質基板に $\mathrm{ZrO}_{2}$ 電解質を スパッタした薄膜型も開発されている30)。Fig. 17に薄膜 型の構造図を示す。可熱性ガスを対象とする場合には, 両極間に電池起電力が発生するので，両電極を短絡した 時の短絡電流值からガス濃度を検出する電解質にプロト ン導電体を用いた素子が試作され，小型多機能化の可能 性が発表されている。Fig.18にプロトン導電体式積層型 厚膜素子の構造を示す 31 。

\section{5. 電解質溶液を用いる電気化学式ガスセンサ32)}

イオン導電相に電解質溶液を用いる電気化学式がスセ ンサは古くから開発使用されている。定電位電解式とが ルバニ電池式との二つがある。ここでは, 構造上の理由 等より小型化が難しく，複合化の可能性が低いので説明 は省略させてもらうが，このタイプも寿命等の改良は続 けられており, 最近, ガルバニ式酸素センサとして 5 年

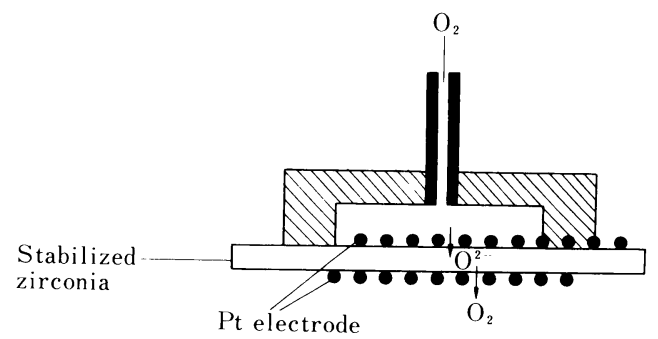

(a) Structure

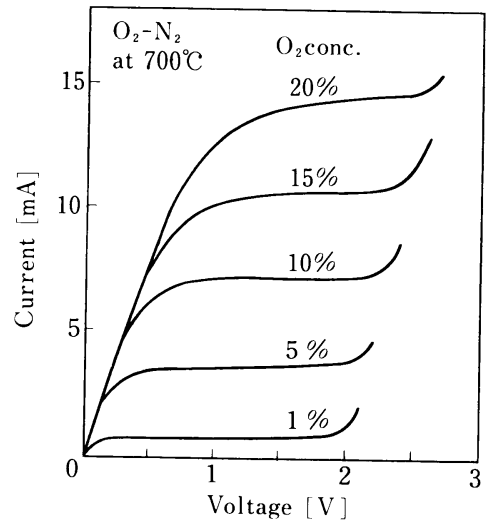

(b) Current-Voltage characteristics

Fig. 16 Structure of the capillary type oxygen sensor ${ }^{28}$
以上寿命があるものが開発され発売されている。

\section{6. 接触燃焼式ガスセンサ ${ }^{33)}$}

pt線に酸化活性の高い触媒物質を披履した素子に可燃 性がスを含む空気を接触させると，触媒上で可燃性ガス と酸素との反応に伴う燃焼熱により pt線の抵抗が変化す ることを利用したものであるが, 半導体と比較して披検 ガスに対して濃度依存性がほぼ直線的で, 定量性に優れ 高級型の可熱性ガス検知器用として多量に使用されてい るが, 微量がスに対してやや感度が悪く, その構造性か らもインテリジェント化や複合化には不向である。

\section{7. 水晶振動式ガスセンサ}

水晶振動子の表面に薄膜（塗布膜）を固着すると，共 振周波数が塗布膜の重量に比例して, 次式のように変化 する。

$$
\Delta F=2.3 \times 10^{6} \times F^{2} \times \Delta W / A
$$

ここで $F$ : 水晶振動子の共振周波数 $[\mathrm{MHz}], \Delta F$ :

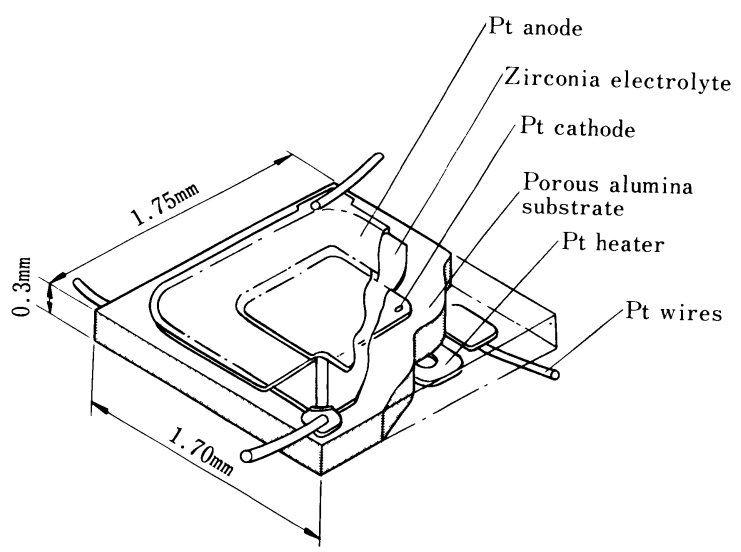

Fig. 17 Structure of thin film limiting current-type oxygen sensor ${ }^{30}$

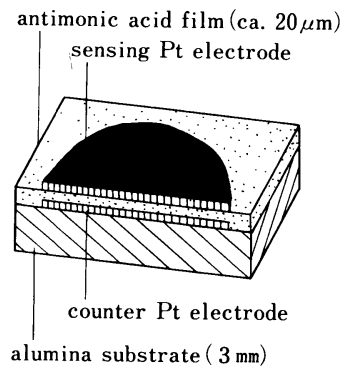

Fig. 18 Structure of the modified amperometric sensor 31) 
その変化 $[\mathrm{Hz}], \Delta W$ : 塗布膜重量 $[\mathrm{g}], A$ : 叙布膜 面積 $\left[\mathrm{cm}^{2}\right]$ である。

一般に, 水晶振動子の重量検出限界は約 $10^{-12} \mathrm{~g}$ に对す るともいわれ，塗布膜へのガス吸着時に起こるわずかな 重量増加に伴う周波数変化からガスを検知しようとする ものである。素子構造をFig. 19に示すが， $3 \sim 10 \mathrm{MHz}$ の共振周波数をもつATカット振動子の両面に $\mathrm{Au}$ 電極を 蒸着し，さらにその上にガスを選択的に吸収する塗布膜 を形成している。ガス検出感度が高いので極微量が問題 となる $\mathrm{SO}_{2}$ や $\mathrm{NH}_{3}$ 等の有毒がス検知に適している34),35)。 また最近，このセンサを複数個用いた臭いセンサ等が試 作され，インテリジェントセンサの可能性を示唆され ているが, 塗布膜の寿命が 1 开月程度であることが 本センサへの実用化への妨げとなっている。

\section{8. まとぬ}

現状のガスセンサについて, 雑ぱくに述べてきたが, ガスセンサのハイブリッド化は，今後に期待するところ が大である。半導体式のMOSFETやMISダイオードガ スセンサが，そのハイブリッド化に最も近い位置にあり， 使用面を考えた実用化は期待できる。耐久性や応答速度 の面からは, 半導体厚膜印刷型 (加熱型電気抵抗式) 素 子をより小型し, さらにがス選択性の向上をはかる研究 が進行中であり ${ }^{36)}$ ， ハイブリッド化されたインテリジェ ントセンサも，近い将来実現化されると考える。ところ で，ハイブリッド化センサを開発するうえで必要なこと は, 使用目的の分類や使用条件等の整理にあるが，その 複雑さの為に研究が立ち遅れている。それらのソフト化 技術の促進がぜひ必要である。

\section{9.おわりに}

一部のガスセンサしか扱っておらず，さらに，ハイブ リッド技術等, 門外漢の私がガスセンサのハイブリッド 技術を紹介する等おこがましい限りであるが，1 人のセ ンサ屋として, 人間の感覚に代る臭気センサや煙がスセ ンサは夢であり，いつも一歩近づいたセンサにしたいと 望んでおり，その勉強の意味でこの文章を書かせてもら った。それゆえに, 電子, 電気技術の専門家の方等には, ハイブリッド化センサの製造方法の説明で不満足なとこ ろが多くみられたと思う。引用文献を参考にしていただ くことで，お許し願いたい。最後に資料の提供を御許可 をいただいた山添昇教授にお礼を述べる。

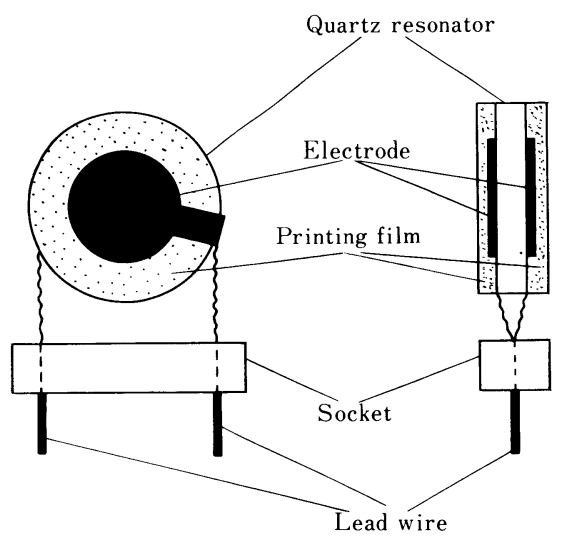

Fig. 19 Structure of the quartz resonance type sensor ${ }^{35)}$

\section{参考・引用文献}

12) A.IKEGAMI他 : Transducer'85, Digest of Technical Papers, p.136, (1985)

13）松同道雄他: National Technical Report, 24, p.461, (1978)

14）桜井洋他：電気学会電子装置研究会質料, FDD-75-48, (1975)

15） T.Y.Tien他 : Am, Ceram.Soc.Bull., 54, 280, (1975)

16）清山哲郎監修：化学センサ実用便覧，p.96〜97, フジ・テク， システム, (1986)

17) 安形和俊他：第 5 回化学センサ研究発表会要旨集, p.59 60, (1986)

18） I.Lundstrom他: Appl. Phys, Lett., 26, p.155, (1975)

19) M.Armgarth他: Digest of Technical Papers, Transducers '85, Phyladelphia, p.235, (1985)

20) K.Dobos他 : Proc. Intern, Meeting on Chemical Sensors,

Fukuoka, p.464, (1983)

21) M.Higikigawa他: Digest of Technical Papers, Transducers '85, Phyladelphia, p.221, (1985)

22) J.Kimura他: Digest of Technical Papers, Transducers ' 85 , Phyladelphia, p.152, (1985)

23） N.Yamamoto他: Surf. Sci., 92, 402, (1980)

24） N.Yamamoto他: Surf. Sci., 146, (1984)

25) R.C.Hughes'87, Tokyo, p.635 639, (1987)

26）山本達夫他：薄膜第131委員会, 第125回研究会質料, (1984)

27）清山哲郎監修：化学センサ実用便覧, p.404, フジ・テクノシ ステム, (1986)

28）佐治啓市他：第 4 回「センサの基礎と応用」シンンポジウム予 稿集, p.37, (1984)

29）中沢光博他：電子材料, p.115 119, （1985）

30) 高橋英昭他：第 4 回化学センサ研究発表会要旨集, p.41 42, (1985)

31）清水陽一他：第 7 回化学センサ研究発表会要旨集, p.101 104, (1988)

32）磯部満夫：センサ技術， 4 (13)，27，（1984）

33）彦坂亘宏他：矢崎技術レポート, Vol. 2, p.84 90, (1977)

34）清山哲郎編他：化学センサー, p.116, 講談社, (1982)

35） J.Hlavay他 : Anal. Chem., 49(13), 1980, (1977)

36) 中原毅他：第 6 回化学センサ研究発表会要旨集, p.21 22, (1987) 